\title{
THE GENUS ANTEMETULA REHDER IN THE INDO- WESTPACIFIC AREA, WITH THE DESCRIPTION OF TWO NEW FOSSIL SPECIES
}

\author{
BY \\ C. O. VAN REGTEREN ALTENA \\ Rijksmuseum van Natuurlijke Historie, Leiden
}

\section{INTRODUCTION}

ReHDER (1943: 199) pointed out, that Buccinum clathratum Adams \& Reeve, 1848 , is the type of the genus Metula H. \& A. Adams, 1858. For the species congeneric with Buccinum metula Hinds, 1844 , he proposed the generic name Antemetula, with that species as the type:

Buccinum metula was described by Hinds from a specimen dredged by the Sulphur off the West coast of Veragua, at a depth of a few fathoms. There are no other records of the species from the American West coast. Sмiтh (1904: 465) called attention to the fact that young specimens of Buccinum mitrella Adams \& Reeve, I848, match Hinds's figure of $B$. metula. B. mitrella was described from one or more specimens dredged by the Samarang in the China Sea, at a depth of Io fathoms, and has been recorded since from some more localities in the Indo-Westpacific area. SмIтн thought $B$. mitrella $a$ to be a synonym of $B$. metula, and the type locality of the latter possibly erroneous. It is, indeed, unlikely that a benthonic prosobranch inhabiting the West coast of America between the tropics will also occur in the Indo-Westpacific area, because the eastern Pacific barrier is practically insurmountable for littoral species, as EKMAN (1935: 105-107) has shown. If therefore SMIтH's opinion, that $B$. mitrella is a synonym of $B$. metula be right, the type locality mentioned by Hinds must be wrong. The Sulphur dredged in the China Sea also, and therefore it seems possible that material from that sea was confounded with shells from the American West coast.

Everyone comparing young shells of Buccinum mitrella with Hinds's figure of $B$. metula must be struck by the great resemblance between these two. Unfortunately, however, the type of $B$. metula is not in the British Museum, as Dr. W. J. ReEs kindly informs me, and the synonymy supposed by SMrth cannot be proven. Therefore all the records of the species from the Indo-WestBijdragen tot de Dierkunde, Afl. 28. 
pacific area resembling $B$. metula have been kept under the heading Antemetula mitrella in this paper.

\section{THE GENUS ANTEMETULA}

Antemetula Rehder, 1943, Proc. U. S. Nat. Mus., 93, no. 3161 : 199.

Type species (original designation): Buccinum metula Hinds, I844 1).

Fusiform, slender buccinids, with a delicate decussate sculpture all over the shell. Outer lip somewhat thickened, old apertures showing more or less clearly as varices on the older whorls. Columella smooth, no parietal tooth, palatal wall of aperture finely plicate, canal short. Protoconch paucispiral and consisting of $\mathbf{I}-2$ smooth whorls, or multispiral, conoid, and consisting of $21 / 2-5$ whorls of which the younger ones bear keels. Operculum unknown. Radula: rhachidian tooth with five cusps, laterals with three, of which the medial is by far the largest.

All the recent and fossil species from the Indo-Westpacific area hitherto assigned to the genus Metula are here considered to belong to Antemetula, excepting Fusus (Metula ?) philippinarum Watson, 1882.

Lower Miocene: Karachi, Java.

Upper Miocene: Java, Timor.

Pliocene: Sumatra, Java, Timor, Ceram, Taiwan (Formosa)

Recent: Gulf of Oman, Indian Ocean, China Sea, Suruga Gulf (Japan), ? off West coast of Veragua. Io-156 fathoms.

Thiele (1929: 314) assigned his new subgenus Appisania, type Pisania montrouzieri Crosse, 1862, to the genus Metula H. \& A. Adams on account of the characters of the radula. Thiele took Metula in a wide sense, including the species here assigned to Antemetula. The only species of Metu!a thus conceived of which the radula is known, is a species belonging to Antemetula, viz. A. mitrella (Adams \& Reeve). Therefore the group Appisania, which future research may show to contain more species hitherto assigned to Pisania, seems to be the group most related to Antemetula which at present occurs in the Indo-West-pacific area.

Some recent species of "Metula" have been described from the Carribean Sea : they closely resemble the species here assigned to Antemetula. They are: Metula lintula Guppy, 1882, $M$. amosi Vanatta, 1913, and $M$. fusiformis Clench \& Aguayo, 194I. They seem, however, to have developed in loco, as several apparently closely related species have been described from the neogene tertiaries of the same region. Nothing is known of the anatomy of the Carribean species, and moreover a closer comparison of these species with Antemetula on conchological lines, with special attention to the characters of the apex,

1) Antemetula metula (Hinds). Buccinum metula Hinds, I844, Zool. Voy. Sulphur, 2: 31, pl. I6 f. 13, 14. ?Metula Hindsii H. \& A. Adams, 1858, Gen. Rec. Moll., I: 84. Metula Hindsü Tryon, 188I, Man. Conch., 3: 153, pl. 72 f. 240. 
might reveal differences. The Carribean group of species and the genus Antemetula may have developed independently from -common palaeogene ancestors.

As long as the anatomy of Buccinum clathratum Adams \& Reeve, described from Cape of Good Hope, but which Tomlin (I927: 160) has shown to be an inhabitant of the Northwest coast of South America *), is unknown, the relation of Antemetula to the genus Metula H. \& A. Adams will remain unclear.

\section{KEY TO THE INDO-WESTPACIFIC SPECIES OF ANTEMETULA}

I. Bodywhorl 8/1 I of total height in adult shell . . . . I. martini II. Bodywhorl less than $8 / \mathrm{II}$ of total height in adult shell

A. Shell very slender, varices not conspicuous

a. Altitude $25 \mathrm{~mm}$, protoconch about $23 / 4$ whorls, with both spiral keels and axial ribs . . . . . . . . . . 8. mitrella

aa. Altitude $35 \mathrm{~mm}$, protoconch unknown . . . 9. elongata

B. Less slender, varices more or less conspicuous, protoconch smooth, or with spiral keels only (sometimes youngest whorl of protoconch finely wrinkled in axial direction)

a. Protoconch multispiral ( 3 or more whorls), its youngest whorls with spiral keels

b. Youngest whorl of protoconch bearing 3 spiral keels . 2. beauforti bb. Youngest whorl of protoconch bearing 2 spirals

c. Altitude $32 \mathrm{~mm}$, sculpture coarser than in daphnelloides, protoconch $3 \frac{1}{4} 4-3 \frac{1}{2}$ whorls . . . . . . . . 3. $i h^{\prime} e i$

cc. Altitude $26 \mathrm{~mm}$, sculpture finer than in daphnello:des, protoconch about 3 whorls . . . . . . 4. andamanica

ccc. Altitude $18 \mathrm{~s} / 2 \mathrm{~mm}$, protoconch $33 / 4-5$ whorls 5 . daphnelloides

aa. Protoconch paucispiral (less than 2 whorls)

b. Youngest whorl of protoconch with one keel . $\quad 6$. jonkeri

bb. Protoconch wholly smooth . . . . . . . 7.boettgeri

\section{SURVEY OF THE INDO-WESTPACIFIC SPECIES OF ANTEMETULA}

I. Antemetu'a martini (Vredenburg).

Metula martini Vredenburg, 1923, Rec. Geol. Survey India, 55: 70 (nom. nud.); 1925, Mem. Geol. Survey India, 50: 195, pl. 9 f. sa, b.

VREDENBURG gives the following measurements of the unique type: altitude

*) After the present paper had gone to press, I found that Smith (1896, Ann. Mag. Nat. Hist., (6) 18: 370) records an exceptionally large specimen of this species from off Ceylon, $180-217 \mathrm{fms}$. 
22, diameter 7, height of spire 11 , height of bodywhorl $16 \mathrm{~mm}$. In his figure, however, which is said to be $\times 2 / \mathrm{r}$, the bodywhorl has a height of 16 , the spire of $6 \mathrm{~mm}$. So there must be some mistake in these data. It is here assumed that the figure represents the specimen natural size, and that consequently the height of the spire is $6 \mathrm{~mm}$.

Lower Miocene (Gaj beds): Karachi, India.

2. Antemetula beauforti spec. nov. (Figure I).

Metula boettgeri [non Martin] Pannekoek, 1936, Altmioc. Moll. Rembang : 41, pl. 2 f. 20.

Description: Shell of the usual Antemetula habitus and with the delicate decussate sculpture characteristic of the genus. Whorls about $8 \mathrm{I} / 2$, somewhat convex. There are some conspicuous varices in the spire. The nucleus is missing. Probably the protoconch consisted of 4 whorls, of which the first $1 \frac{1}{4}$ were smooth. Then a peripheral keel appears; the third whorl is bicarinate, the fourth bears 3 keels, and a fourth keel starts on the youngest portion of the fourth whorl. These 4 keels correspond with the four spirals on the oldest whorl of the definite shell. The second half of the last whorl of the protoconch bears close set axial wrinkles. As the outer lip is damaged, the characters of the aperture cannot be examined. Altitude $18 \mathrm{t} / 2$, diameter $51 / 2 \mathrm{~mm}$.

I have named this new species after my highly esteemed master of zoogeography, Prof. Dr. L. F. DE Beaufort.

Antemetula beauforti is very nearly related to both $A$. ihlei and $A$. boettgeri. From the first it differs by the sculpture of the protoconch, by the definite sculpture being a trifle finer, and perhaps by its smaller size; from the second mainly by the totally different protoconch.

Lower Miocene (Rembang beds): ! Sedan ${ }^{2}$ ), Residence of Rembang, Java.

The unique specimen of this species was recorded as "Metula boettgeri Mart." by miss Pannekoek. Although she described the protoconch, she apparently did not notice that it was virtually different from that of MARTIN's species.

3. Antemetula ihlei spec. nov. (Figure 2).

Metula Boettgeri [non Martin] Tesch, 1915, Palaeont. Timor, 5, no. 9: 54, pl. 81 f. I16.

?Metula spec. I Martin, 1928, Wetensch. Meded. Mijnb. Ned.-Indië, 10: 10, 19; Van der Vlerk, 193I, Leidsche Geol. Meded., 5: 23 I.

Metula boettgeri Van der Vlerk, 1931, Leidsche Geol. Meded., 5: 231 (partim).

Antemetula spec. A v. R. Altena, 1949, Leidsche Geol. Meded., ?: ?, no. 243 (in the press).

Description: As this new species can only be distinguished from $A$. boettgeri by the shape of the protoconch, a description of that part of the shell only will follow here. Protoconch conoid, consisting of $3 \frac{1}{4}--3 \frac{1}{2}$ whorls, bearing

2) The names of localities from which the author examined specimens are preceded by a ! 

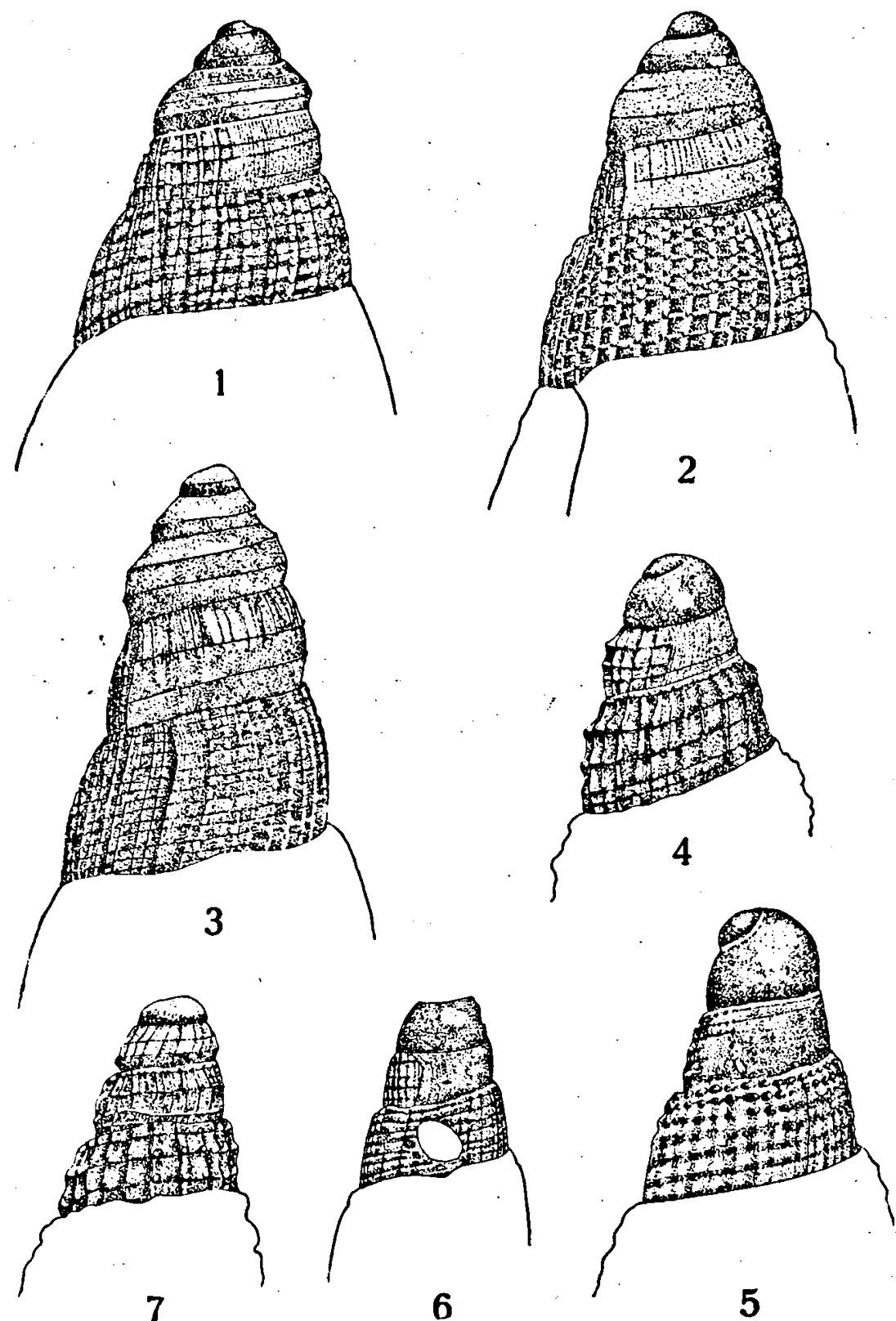

Figure I-7. Protoconchs of various species of Antemetula, $\times 16$.

I : $A$. beauforti sp. n. (holotype); $2: A$. ihlei sp. n. (holotype); $3: A$. daphnelloides (Melvill \& Standen) (Savu Sea); 4:A. jonkeri (Koperberg) (holotype); $5: A$. boettgeri (Martin) (lectotype); 6: $A$. boettgeri (Martin) (locality M 257, Residence of Madioen, Java); 7:A. mitrella (Adams \& Reeve) (pliocene, Ceram). 
two spiral keels, of which the first one originates on the youngest part of the first whorl, the second (posterior) one occurs on the last whorl of the protoconch only. For the rest the surface of the protoconch is smooth, except the youngest $1 / 2$ of the last whorl, in which fine, close set, axial wrinkles are visible.

Altitude 25, diameter $8 \mathrm{~mm}$ (holotype). The altitude of a damaged specimen from the Poetjangan layers may be estimated at $32 \mathrm{~mm}$, diameter $9 \mathrm{~mm}$.

I have named this new species in honour of my highly esteemed master of zoology, Prof. Dr. J. E. W. Ihle.

Metula spec. I Martin from the Pliocene of Atjeh is said to be closely related to $A$. boettgeri, but to differ by a slightly coarser sculpture and by the apex, therefore it may be the present species.

Pliocene: (main fossil bed): ? Atjeh (Martin); (Upper Kalibeng beds = Sonde beds): ! Locality $M \mathbf{2 5}^{2^{3}}$ ), Residence of Madioen, Java (type locality) (v. R. Altena); ! Valley of the Noil Besi, Timor (Tesch).

Pleistocene (Poetjangan layers): ! Localities $\mathrm{M}$ IOI and $\mathrm{M}$ 301 ${ }^{4}$ ), Residence of Soerabaja, Java (v. R. Altena).

4. Antemetula andamanica (E. A. Smith).

Metula andamanica Smith, 1906, Ann. Mag. Nat. Hist., (7) 18: 165.

Unfortunately this species has not been figured. The specimens here described as $A$. ihlei almost exactly match SмIтн's description, but they show a sculpture coarser than that of $A$. daphnelloides, while in andamanica it should be finer.

Recent: Off Port Blair, Andaman Islands, roo fms.

5. Antemetula daphnelloides (Melvill \& Standen) (Figure 3).

Metula daphnelloides Melvill \& Standen, 1903, Ann. Mag. Nat. Hist., (7) 12: 307, pl. 22 f. 9; Schepman, 1911, Prosobr. Siboga Exp.: 310; Woodring, 1928, Publ. Carnegie Inst., $385: 286$.

In the original description the number of ap:cal whorls of this species is said to be $4 \frac{1}{2}$; in the discussion added to the description it is "four to five". The specimens dredged by the Siboga have $33 / 4$ apical whorls, whereas a specimen from the Gulf of Oman in the British Museum, which Dr. W. J. ReEs was so kind as to send me on loan, shows $4 \frac{1}{4}$ of them. This specimen is the largest I saw, it measures: altitude $18 \mathrm{r} / 2$, diameter $6 \mathrm{~mm}$. Adult specimens of this species can be distinguished at a glance from other species of the genus by the somewhat expanding basal part of the outer lip.

Recent: Gulf of Oman, $156 \mathrm{fms}$ (type locality); ! Gulf of Oman, $50 \mathrm{fms}$, F. W. Townsend (British Museum); ! Savu Sea, $274 \mathrm{~m}$ (Schepman).

3) Cf. v. R. Altena, 1938, Leidsche Geol. Meded., 10: 256.

4) Cf. v. R. Altena, I938, Leidsche Geol. Meded., 10: 251, 257. 


\section{Antemetula jonkeri (Koperberg) (Figure 4).}

Metula jonkeri Koperberg, I931, Jaarb. Mijnw. Ned. O.-Indië, 1930, Verh., I:. IoI, pl. 3 f. 38 .

More material is required for us to judge about this species. The protoconch is very near that of $A$. boettgeri, but it differs by possessing a basal keel on the youngest part of the last whorl.

Upper Miocene: ! Toi Osapi Sòka or Nono Fatoe Fekoe, Timor.

\section{Antemetula boettgeri (K. Martin) (Figures 5, 6).}

Metula Boettgeri Martin, 1899, Samml. Geol. Reichsmus. Leiden, (N. S.) I: 221, pl. 21 í. 318, ? 317, 317a, b; 1906, Ibidem: 310; 1919, Palaeozool. Kenntn. Java: 83 (partim), 132, ? 141; ? Zwierzycki, 1915, Jaarb. Mijnw. Ned. O.-Indië, 1913, Verh.: 127.

?Metula Zwierzycki, op. cit. : I 10.

?Metula Boettger [sic] Zwierzycki, op. cit.: 129.:

Metula boettgeni Van der Vlerk, 1931, Leidsche Geol. Meded., 5: 23I (partim).

Antemetula boettgeri v. R. Altena, 1949, Leidsche Geol. Meded., ?: ?, no. 242 (in the press).

The specimen from the Menenteng ravine described and figured by MARTIN ( 1899, f. 318 ) is here designed as lectotype of this species. The protoconch of that specimen is refigured (fig. 5), because MARTIN's figured proved unsatisfactory. As the upper shell layer is somewhat worn off near the place in which the protoconch merges into the definite shell, this place cannot be located exactly, but the protoconch consists certainly of at most $1 \mathrm{r} / 2$ smooth whorl. The greater part of the bodywhorl is missing in the lectotype ; presumably the altitude of the entire shell was about $30 \mathrm{~mm}$. MARTIN's syntype from the Sonde beds (Martin 1899, f. 317, 317a, b), in which the apex is missing, has to be referred to as Antemetula spec., as it could equally well belong to A. ihlei.

Although the protoconch is damaged in the specimens recorded from locality M 257 of the Sonde beds, there is no doubt that it was of the same type as that of the lectotype, and here the border between protoconch and definite shell is distinct (fig. 6). These shells are not adult, and they are slightly slenderer than the lectotype. Their dimensions are: altitude 21 , diameter $6 \mathrm{r} / 2$ $\mathrm{mm}$, and altitude $20^{\mathrm{T}} / 2$, diameter $6 \mathrm{~mm}$.

Pliocene: ? Kroeë, Residence of Benkoelen, Sumatra (Zwierzycki); ? Ajer Lipai, Residence “Sumatra's Westkust”, Sumatra (Zwierzycki); Menenteng ravine, Residence of Cheribon, Java (type locality); (Upper Kalibeng = Sonde beds): ! ? Sonde, Residence of Madioen, Java (Martin); ! Locality M $257^{5}$ ) near Sonde (v. R. Altena).

\section{Antemetula mitrella (Adams \& Reeve) (Figure 7).}

Buccinum mitrella Adams \& Reeve, 1848, Zool. Voy. Samarang, Moll.: 32, pl. II f. 13. Metula mitrella H. \& A. Adams, I858, Gen. Rec. Moll., I: 84; Troschel, I866-'93, Ge-

5) Cf. v. R. Altena, 1938, Leidsche Geol. Meded., 10: 256. 
biss Schnecken, 2: 78, pl. 7 f. Io; Tryon, I88I, Man. Conch., 3: 152, pl. 26 f. 21, pl. 72 f. 239; Nomura, 1935, Sci. Rep. Tohoku Imp. Univ. Sendai, (2) 18: 149, pl. 8 f. I ; Yen, I942, Proc. Mal. Soc., 24: 230.

Metula Hindsii Martin, I884, Samml. Geol. Reichsmus. Leiden, (1) 3: 106, pl. 8 f. 143; Tesch, 1915, Palaeont. Timor, 5, no. 9: 53, pl. 81 f. 1 I5; Martin, 1919, Palaeoz. Kenntu. Java : 83, 134; Fischer, 1927, Palaeont. Timor, 15, no. $25: 8 \mathrm{I}$.

Metula metula Melvill \& Standen, 1903, Ann. Mag. Nat. Hist., (7) 12: 307; Ludwig, I933, Geol. kaart Java, Toel. blad 30: I5.

Metula Hindsi Smith, 1904, Ann. Mag. Nat. Hist., (7) 13: 464.

Buccinum mitrellum Woodring, 1928, Publ. Carnegie Inst., 385: 286.

Metula spec. 2 Martin, I乌̧28, Wetensch. Meded. Mijnb. Ned.-Indië, ro: Io.

Metula hindsii Van Es, 1931, Age Pithecanthr.: 69; Van der Vlerk, 193I, Leidsche Geol. Meded., 5: 231.

I was able to compare some specimens from the Pliocene of Ceram with Recent ones of the British Museum collection, and they appeared to agree in every respect. A specimen of Metula spec. 2 Martin from the pliocene of Atjeh, which belongs to the Rijksmuseum van Geologie en Mineralogie at Leiden, could be identified with this species.

Upper Miocene: ! Ngembak, Residence of Semarang, Java (Martin); (Tjidadap layers): Tjikao, Residence of Batavia, Java (Ludwig).

Pliocene: (main fossil bed) : ! Atjeh (Martin); Kalioeter, Government of Soerakarta, Java (Van Es) ; ! Between Noil Noni and Pene, Timor (Tesch); (Fufa layers): ! Ceram (Fischer); (Byôritu beds): Taiwan (Nomura).

Recent: China Sea, Io fms (type locality); ! China Sea (Yen); Philippines (Troschel); off Coromandel coast, 4I fms (Smith); Gulf of Oman, I56 fms (Melvill \& Standen).

\section{Antemetula elongata (Dall).}

Metula elongata Dall, 1907, Smiths. Misc. Coll., 50: 166; 1925, Proc. U. S. Nat. Mus., 66 , art. 17 (no. 2554): 20, pl. 23 f. 4.

Dr. Harald Rehder of the United States National Museum, Washington, kindly provided me with excellent photographs of the type of this species. Unfortunately the apex, which proves to be of so great diagnostic value, is missing. I would not wonder if it appeared to be a large form of $A$. mitrella. The difference in proportion to which DALL calls attention may be due to growth: when shells of this shape grow, the relation $\frac{\text { height bodywhorl }}{\text { total height }}$ diminishes.

Recent: Suruga gulf, Japan, 57 fms.

? Antemetula spec.

Metula n. sp. Van Raalte, 1937, Geol. kaart Sumatra, Toel. blad 7: 18.

Pliocene (middle part of Upper Palembang layers): Bintoehan, locality e, E. of Barisan, Sumatra. 


\section{SOME REMARKS ON THE NINE SPECIES RECORDED}

Unfortunately the material at hand and the information in literature are insufficient to judge the real value of the 9 "species" recorded above. Future research may show some of them to be subspecies or even varieties. Three fossil and two recent species are represented by the type only, so we do not know anything about their variability.

The shells of $A$. boettgeri and $A$. ihlei can only be distinguished by their protoconchs. There is evidence that external factors may influence the shape of the larval shell in prosobranchs, and therefore the question arises if the difference between these two types of protoconchs cannot be due to the environment. There are, however, two reasons why I think this to be highly improbable: (I) the difference between the two types of protoconchs is large, and no transitions are met with; (2) the two types occur in the fauna of the same beds (the Pliocene Sonde beds), in which one would not expect to find forms developed under widely different external circumstances, unless at least one of them has been transported before being embedded, and such is improbable for shells which still possess their protoconchs.

Probably $A$. ihlei, beauforti, andamanica, daphnelloides, and mitrella had or have larvae with a long pelagic life, whereas $A$. jonkcri and boettgeri hatched as bottom dwellers, or had a very short pelagic life. As species with a pelagic larva existed already in the early Miocene, this seems to be the more primitive condition. As far as we know the species developing immedately into bottom dwellers are restricted to the upper Miocene and Pliocene.

\section{LITERATURE}

Ekman, Sv., 1935. Tiergeographie des Meeres. Leipzig, XII + 542 pp., 244 figs.

Martin, K., I899. Die Fossilien von Java auf Grund einer Sammlung von Dr. R. D. M. Verbeek bearbeitet. Mollusken, Heft 5-7. Samml. Geol. Reichsmus. Leiden, (N.S.) I : 133-221, pls. 21-33.

Rehder, H. A., 1943. New marine mollusks from the Antillean region. Proc. U. S. Nat. Mus., 93, no. 3161 : 187-203, pls. 19, 20.

Smith, E. A., 1904. Natural History Notes from H. M. Indian Survey Steamer "Investigator", Commander T. H. Hemming, R. N. - Series III, No. I. On Mollusca from the Bay of Bengal and the Arabian Sea. Ann. Mag. Nat. Hist. (7) 13: 453-473.

Thiele, J., I929. Handbuch der systematischen Weichtierkunde, I, part I. Jena, 376 pp., 470 fig.

Tomuin, J. R. le B., I927. The mollusca of the "St. George" expedition. (I) The pacific coast of S. America. Journ. of Conch., I8: 153-170. 